\title{
RAMARIA RUBELLA (SCHAEFF.) R.H. PETERSEN - THE FIRST RECORD IN CENTRAL AND EASTERN EUROPE
}

\author{
JANUSZ ŁUSZCZYŃSKI \\ Department of Botany, Institute of Biology, Świętokrzyska Academy \\ Świętokrzyska 15, 25-406 Kielce, Poland \\ e-mail: jluszcz@pu.kielce.pl
}

(Received: March 18, 2007. Accepted: January 18, 2008)

\begin{abstract}
Ramaria rubella (Schaeff.) R.H. Petersen is a very rare species in Europe. Until now it was known only from a few countries. A new site in Poland is the first record from Central and Eastern Europe. Ramaria rubella (subgen. Lentoramaria) belongs to xylobiontic species connected with coniferous woods. The paper includes detailed description of carpophores and microscopic features, distribution and synonyms.
\end{abstract}

KEY WORDS: Ramaria rubella (Schaeff.) R.H. Petersen, Góry Świętokrzyskie Mts., xylobiontic fungi.

\section{INTRODUCTION}

Synonyms: Clavaria rubella Schaeff. per Krombholz, Consp. Fung. Escul. p. 33. 1821. - Clavaria acris Peck, Rep. N.Y. St. Mus. Nat. Hist. 54: 155. 1901. - Clavaria rubella Schaeff., Fung. Bavar. Palat. 4: 119. 1774. - Ramaria acris (Peck) Corner, Brit. Mycol. Soc. Trans. 44: 235. 1961. - Ramaria apicoalba R.H. Petersen, nom. herb., ined. 1975. - Ramaria testaceoincarnata Marr., Thesis, Univ. Washington, ined. 1968.

Taxonomy: Ramaria rubella (Schaeff.) R.H. Petersen, Am. J. Bot. 61: 739-748. 1974. - Ramariaceae, Aphyllophorales, Basidiomycetes (Domański 1984), Ramariaceae, Gomphales, Hymenomycetidae, Hymenomycetes, Basidiomycota (Hansen and Knudsen 1997), Ramariaceae, Phallales, Agaricomycetidae, Hymenomycetes, Basidiomycota, Fungi (Kirk et al. 2001), Gomphaceae, Gomphales, Phallomycetidae, Agaricomycetes, Basidiomycota, Fungi (Index Fungorum 2007).

\section{Iconography and maps of distribution}

Boletus informaticus 2007 (map); Burt 1922: 23-24, pl. 5, Fig. 30; Chelyabinskaya Krasnaya Kniga 2007 (map); Corner 1970: 257; Corner, Thind 1961: 235; Domański 1984: Table 212; Krieglsteiner 1991: 299, Fig. 871 (map); Marr, Stuntz 1973: 137, Fig. 53, 104; Petersen J. H. 1999: 9; Petersen R. H. 1975: Fig. 9, Pls 6-7; Petersen R. H., Olexia 1967: 768; Schild 1971: 3-6, Table. 33.

\section{Morphology}

The genus Ramaria (Fr.) Bonord. was divided into 4 subgenera: Ramaria, Laeticolora Marr and Struntz, Echinoramaria Corner and Lentoramaria Corner, due to differences in the spores morphology and the structure of vegetative fruit bodies hyphae.
Ramaria rubella belongs to the subgenus Lentoramaria. Its fruit bodies are repeatedly polydichotomically branched, numerous and dense. Branches towards base are covered by whitish mycelial felt, which are gradually being transformed into whitish rhizomorphic strands. Stipe is indistinct, and poorly developed. The colour of the fresh fruit bodies is vinous-cinamon, greyish ochre-purple. When the fruit bodies are dry the colour becomes lighter, ochre-purple, with a distinct dark purple tint. Damaged parts of the hymenium layer are dark purple. Flesh in fresh fruit bodies has watery vinous-purple colour, in the dry fruit bodies pale purple-vinous. Taste delicately bitter, acrid; odour indistinct, little specific. Branches in their upper part are usually sharply pointed; cones about $0.5 \mathrm{~mm}$ long, white in colour. Hymenium amphigenous, dark red-purple when treated with $10 \% \mathrm{KOH}$. Whitish rhizomorphic strands become of raspberry, violet-salmon colour when treated with $10 \%$ $\mathrm{KOH}$, which is a characteristic feature of this species. Spores are ellipsoidal, measuring 6.5-9.5 $\times 4-5.4 \mu \mathrm{m}$, with a distinct apiculus, covered by small warts (Fig. 1). Hyphae monomitic, hyaline, are differentiated in the rhizomorphic strands into two kinds, thin-walled and pseudoskeletal 3-5 $\mu \mathrm{m}$ in diameter, with numerous clamps (the clamps are not always clearly visible!), which are towards septe ampoulelike swollen up to about $35 \mu \mathrm{m}$ in diameter. In the branches flesh the hyphae are from thick-walled to almost full, with the swollen clamps about 2-7 $\mu \mathrm{m}$ in diameter. Basidia are 4-spores, club shaped measuring 35-60×6-8 $\mu \mathrm{m}$. Described specimens belong to the typical variety Ramaria rubella var. rubella. The specimens are deposited in the Herbarium (KTC 3476, KTC 3477 and KTC 3478) of Department of Botany, Institute Biology of Świętokrzyska Academy in the Kielce. 

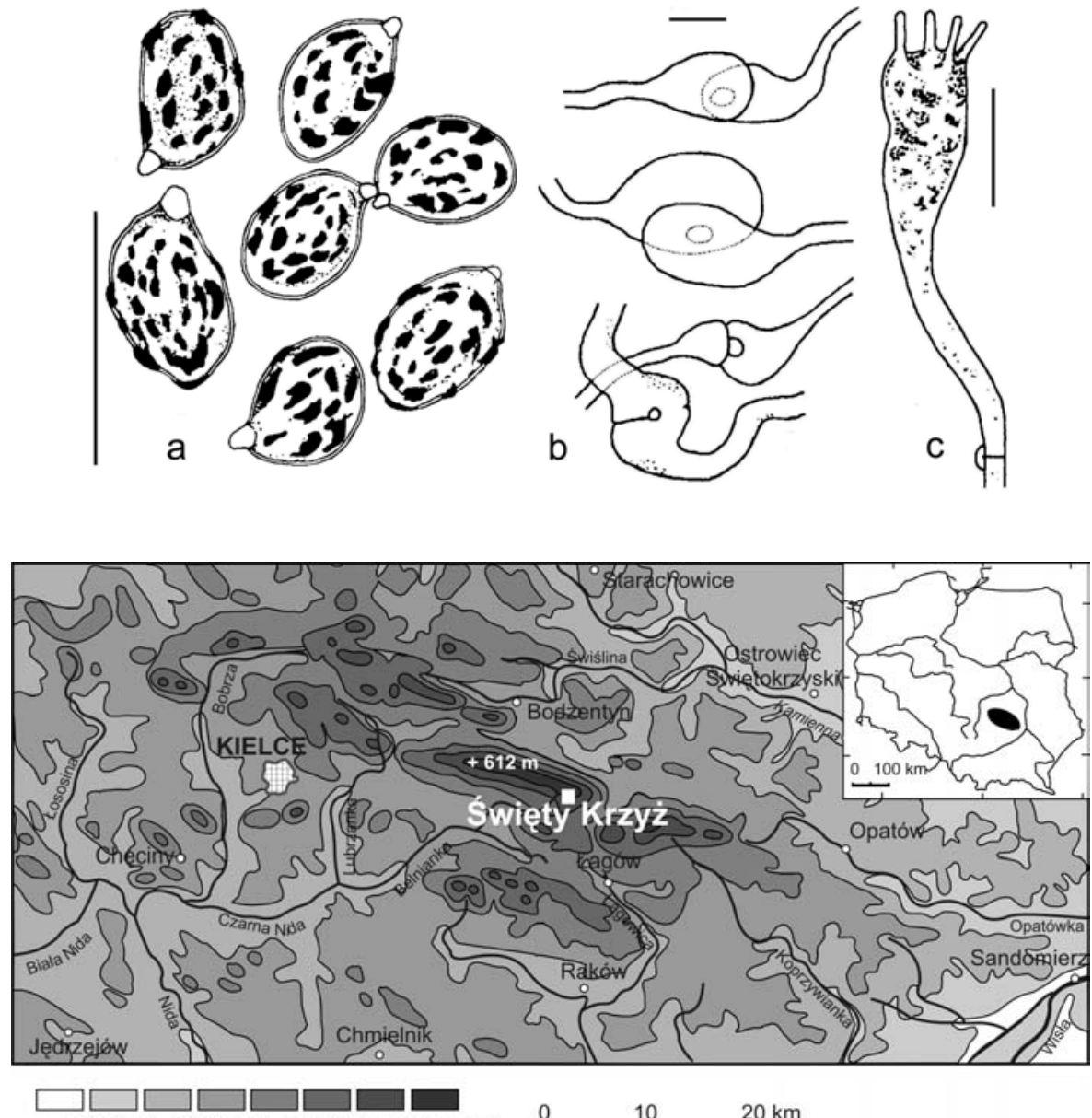

$200 \quad 250 \quad 300 \quad 350 \quad 400 \quad 450 \quad 500$ m a.s.l.

10 $20 \mathrm{~km}$

Fig. 2. Locality of Ramaria rubella in Poland.

\section{Site location}

The described site is situated in the Central Poland, Góry Świętokrzyskie (Holy Cross Mountains), on the N-slopes of Święty Krzyż (Holy Cross, 595 m above see level), forest district 115, in the Abietetum polonicum community (Fig. 2). The fruit bodies grow in groups on rotting wood of Abies alba logs.

\section{Distribution}

Ramaria rubella is a species occurring in the Northern hemisphere. It occurs much more often in North America (Canada, USA) than in Asia (Bhutan, Japan, Russia - Western Siberia, Chelabinskaya oblast') and Europe (Corner 1970; Petersen 1975; Shiryaev 2004). In the European continent it is a rare species, confirmed until now in alpine are-

TABLE 1. Comparison of selected feature of the similar species from the Ramaria genus.

\begin{tabular}{|c|c|c|c|c|c|}
\hline & R. rubella & $R$. polonica & R. apiculata & R. stricta & $R$. gracilis \\
\hline Spores & $\begin{array}{l}6-9.5 \times 4-5.5 \mu \mathrm{m} \\
E=1.31-2.24\end{array}$ & $\begin{array}{l}5.9-8.5 \times 4.1-5.2 \mu \mathrm{m} \\
E=1.31-1.73\end{array}$ & $\begin{array}{l}6.5-10 \times 3.5-5 \mu \mathrm{m} \\
E=1.69-2.80\end{array}$ & $\begin{array}{l}7-10 \times 4-5 \mu \mathrm{m} \\
E=1.69-2.33\end{array}$ & $\begin{array}{l}5-7 \times 3.5-4.5 \mu \mathrm{m} \\
\mathrm{E}=1.27-1.9\end{array}$ \\
\hline System of hyphae & monomitic & monomitic & monomitic & dimitic & dimitic \\
\hline Colour of aksils & white & white & $\begin{array}{l}\text { whitish to light } \\
\text { of green, } \\
\text { malachite-green }\end{array}$ & $\begin{array}{l}\text { yellow, } \\
\text { yellow-ochre }\end{array}$ & $\begin{array}{l}\text { whitish to creme } \\
\text { or yellow-ochre }\end{array}$ \\
\hline Colour of flesh in cross-section & reddish & reddish & $\begin{array}{l}\text { whitish, } \\
\text { none redden }\end{array}$ & brown-vinous-red & yellowish \\
\hline Colour of flesh in $10 \% \mathrm{KOH}$ & dark red-purple & dark red-purple & brownish & $\begin{array}{l}\text { cupper, orange, } \\
\text { brownish }\end{array}$ & unchanged \\
\hline Teste & acrid to stron acrid & undeterminete & mildly crid to bitter & mildly spicy to bitter & $\begin{array}{l}\text { mildly bitterish, } \\
\text { musty-fungal }\end{array}$ \\
\hline Odor & $\begin{array}{l}\text { absent or remainig } \\
\text { to anise }\end{array}$ & fungoid & none & anise & $\begin{array}{l}\text { slowly anise, } \\
\text { when dry faintly } \\
\text { of fenugreek }\end{array}$ \\
\hline
\end{tabular}


as of Austria, Germany, Slovenia, Switzerland and in Scandinavia in Sweden (Hansen and Knudsen 1997; Jülich 1984; Krieglsteiner 1991; Boletus informaticus 2007).

\section{DISCUSSION}

Ramaria rubella displays an interspecies differentiation. Petersen (1975) distinguishes two forms, typical form $R a$ maria rubella f. rubella, occurring in the above-mentioned places, and Ramaria rubella f. blanda Petersen which occurs only on the shores of the Pacific and Atlantic Oceans and in the Appalachian Mountains. The second form is regarded as an endemic form of North America. Thind and Sharda (1985) described a new variety of this species from Bhutan in Himalayan Mountains, Ramaria rubella var. himalaica.

From the morphological point of view Ramaria rubella is similar to the other xylobiontic species such as: $R$. apiculata, $R$. gracilis, $R$. polonica i $R$. stricta. Differences between the listed species are presented in Table 1. Particular attention deserves the similarity of Ramaria rubella and $R$. polonica. Fruit bodies of these species are like twins, and differences regard the structure of hymenium and the size of spores. In hymenium of $R$. polonica (described by Peterson 1975), from the specimens found in the Święta Katarzyna in the Góry Świętokrzyskie (Holy Cross Mountains), there

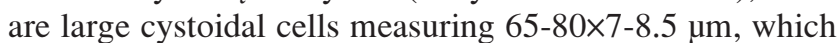
are absent in Ramaria rubella. The size of basidia measuring over $85 \times 7-8.2 \mu \mathrm{m}$ is similar to that of cystoidal cells. Whereas the spores of Ramaria rubella are slightly longer than those of Ramaria polonica (Table 1). The occurrence of such similar species in the same area requires a special care when the identification is carried out in the field without the use of microscope. From the remaining above mentioned species Ramaria rubella differs in a very quick reaction to $10 \% \mathrm{KOH}$ resulting in pink colour of rhizomorphs.

\section{ACKNOWLEDGMENT}

I would like to express my great thanks to Dr. Dušan Jurč and Mr. Nikica Ogris from Slovenian Forestry Institute for information on distribution Ramaria rubella in Slovenia.

\section{LITERATURE CITED}

BOLETUS INFORMATICUS. 2007. [http: //www.gozdis.si/departments/forestprotection/boletus/arealnekarte/slo/bi.htm]
BURT E.A. 1922. The North American species of Clavaria with illustrations of the type specimens. Ann. Missouri Bot. Gard. 9: 1-78.

CHELYABINSKAYA KRASNAYA KNIGA. 2007. [http://igz.ilmeny.ac.ru/RED_BOOK/page1090.html]

CORNER E.J.H. 1970. Supplement to "A monograph of Clavaria and allied genera". Beih. Nova Hedwigia 33: 1-299.

CORNER E.J.H., THIND K.S. 1961. Dimitic species of Ramaria (Clavariaceae). Trans. Brit. Mycol. Soc. 44(2): 233-238.

DOMAŃSKI S. 1984. Basidiomycetes (Podstawczaki), Aphyllophorales (Bezblaszkowe), Clavariaceae, Clavariadelphaceae, Clavulinaceae, Pterulaceae, Stephanosporaceae, Gomphaceae (II), Hericiaceae (II). In: Domański, S. (ed.), Mała flora grzybów (Short guide to the fungal flora). 1(4). Basidiomycetes (Podstawczaki), Aphyllophorales (Bezblaszkowe). Państwowe Wydawnictwo Naukowe, Warszawa-Kraków, pp. 403. (in Polish)

HANSEN L., KNUDSEN H. (eds). 1997. Nordic Macromycetes, Vol. 3. Heterobasidioid, aphyllophoroid and gastromycetoid Basidiomycetes. Nordsvamp, Copenhagen. pp. 444.

INDEX FUNGORUM. 2007. http://www.indexfungorum.org/Names/Names.asp

JÜLICH W. 1984. Die Nichtblätterpilze, Gallertpilze und Bauchpilze, Aphyllophorales, Heterobasidiomycetes, Gasteromycetes. In: Gams, H. (ed.). Kleine Kryptogamenflora. 2b/1. Basidiomyceten. 1. VEB G. Fischer Verlag, Stuttgart-New York, pp. 626.

KIRK P.M., CANNON P.F., DAVID J.C., STALPERS J.A. 2001. Ainsworth and Bisby's Dictionary of Fungi. 9. Ed. CAB International, Wallingford, pp. xi +655 .

KRIEGLSTEINER G.J. 1991. Verbreitungsatlas der Großpilze Deutschlands (West). 1. Ständerpilze. Teil A, Nichtblätterpilze. E. Ulmer GmbH. \& Co., Stuttgart, pp. vi + 416.

MARR C.D., STUNTZ D.E. 1973. Ramaria of western Washington. Biblioth. Mycol. 38: 1-232.

PETERSEN J.H. 1999. Key to the species of Ramaria known from Fennoscandia. University of Aarhus, Institute of Systematic Botany [http://www.mycokey.com]

PETERSEN R.H. 1974. Contribution toward a monograph of Ramaria. I. Some classic species redescribed. Am. J. Bot. 61(7): 739-748.

PETERSEN R.H. 1975. Ramaria subgenus Lentoramaria with emphasis on North American taxa. Biblioth. Mycol. 43: 1-161.

PETERSEN R.H., OLEXIA P.D. 1967. Type studies in the clavarioid fungi. I. The taxa described by Charles Horton Peck. Mycologia 59: 767-802.

SCHILD E. 1971. Fungorum rariorum icones colorate. Pars V. Clavariales. J. Cramer, Lehre, pp. 44 + Figs 33-40.

SHIRYAEV A.G. 2004. Clavarioid fungi of Urals. I. Boreal forest zone. Mycology and Phytopathology 38(4): 59-72. (in Russian with English summary)

THIND K.S., SHARDA R.M. 1985. Proc. Indinan Acad. Sci., Pl. Sci. 95(1): 60 